\title{
FINANCIAL PERFORMANCE ANALYSIS IN THE INFLUENCE OF ENVIRONMENTAL PERFORMANCE AND ENVIRONMENTAL DISCLOSURE WITH MODERATING BY ORGANIZATION CULTURE
}

\author{
Yuni Rosdiana \\ Student Doctoral Program Faculty of Economics and Business, University of Trisakti, Indonesia \\ Lecturer in Accounting Department, Faculty of Economics and Business, Unisba, Indonesia
}

\section{Sekar Mayangsari}

Faculty of Economics and Business, Trisakti University, Indonesia

\begin{abstract}
This study aims to analyze financial performance that is influenced by environmental performance and environmental disclosure by moderating by organization culture. The analysis used is descriptive and verification analysis. The sample used is companies listed on the Indonesia Stock Exchange from 2014 to 2017 in the manufacturing sector. The company is a PROPER with gold, green and blue ratings and has a positive ROA value. Samples that met these criteria during the period 2014 - 2017 were 163 samples. The results showed that financial performance was positively influenced by environmental performance by 5.2 and positively environmental disclosure by 3.463. Another thing, organizational culture is not able to increase the effect of environmental performance and environmental disclosure on financial performance and even weaken environmental performance by 70,701. Based on this research, environmental management and disclosure is a positive signal for investors in considering investment decision making so that it can improve the company's financial performance, while the organization culture is still implemented to maintain the company's performance in other fields.
\end{abstract}

KEYWORDS: environmental disclosure, environmental performance, financial performance, and organization culture

JEL Classification : M41, M49

\section{INTRODUCTION}

Financial performance is a benchmark in assessing the level of success of a company by analyzing financial information published by the company and reflected in the company's financial ratios (Myšková \& Hájek, 2017). One of the successes of a company is financial stability where the company is able to generate profits, increase capital value and pay shortterm and long-term obligations (Myšková \& Hájek, 2017). Activities related to financial performance include environment activity (Danso et al,2019, Liu, 2020, Petitjean, 2019, Tzouvanas et al, 2019, Wang \& Yang, 2020), stakeholder policies in companies (Baah, Jin, \& Tang, 2020), energy efficiency (Moon \& Min, 2020), corporate governance ( Al-ahdal et al, 2020), networks rich in diverse business ties (Etriya, 2019), corporate social responsibility (CSR) (Franco et al, 2019; Petitjean, 2019), non-financial performance measures (Gan, Park, $\&$ Suh, 2020), efficient sustainable financial practice activities (Jan et al, 2019), digital business strategies (Ukko et al, 2019), company characteristics, age of management, team size, international experience, government background, education level, (Ma et al, 2019), innovation 
(Rezende et al, 2019), supply chain dynamics (Yu et al, 2019), individual transferable quotas (ITQs) in the fisheries economy (Edwards \& Pinkerton, 2020), quality management (Franco et al., 2019), epidemic diseases (Kim et al, 2020), gender (Valls Martínez \& Cruz Rambaud, 2019), heterogeneity of knowledge of top management, ownership structure (Cui et al, 2019), stakeholder integration (Danso et al., 2019), good corporate governance (GCG) (Iqba et al, 2019), company size (Lin et al, 2019), dan intellectual capital (Sardo et al, 2018). Of all these activities, activities that are still interesting to study and relate to financial performance are environmental activity.

Companies that pay attention to high environmental will get high financial benefits as well (Tzouvanas et al., 2019). Environmental activities related to financial performance are environmental performance (Tzouvanas et al., 2019) and environmental disclosure (Wang et al., 2020). Environmental performance is a management effort in creating environmentally friendly which is currently being promoted by the government through environmental balance in product and service activities in achieving superior performance that can be displayed through performance (Tjahjono, 2013). Environmental disclosure is the company's effort to care and be responsible for the environment that is revealed in the report at the end of the year (Deswanto \& Siregar, 2018). By disclosing this information, the company's image and reputation will improve where it is a positive signal for investors. Research that has been conducted includes research conducted by Eiffeliena (2010) which states that economic performance is not affected by environmental performance and environmental disclosure (Wany et al , 2017), research conducted by Titisari et al. (2012) states that financial performance in PROPER companies is not influenced by environmental performance (Titisari \& Alviana, 2012), and research conducted by Nyilasy (2014) and Lu (2018) states that financial performance is negatively influenced by environmental performance ( $\mathrm{Lu} \&$ Taylor, 2018; Nyilasy et al, 2014). The research conducted are different from the studies conducted by Ahmadi (2017), Longoni and Cagliano (2018), and Wang et. all. (2019) where environmental disclosure is positively related to environmental performance (Ahmadi \& Bouri, 2017; Longoni \& Cagliano, 2018; Wang et al., 2020), Tzouvanas et. all. (2019), Liu (2019) which states that financial performance is positively influenced by environmental performance (Liu, 2020; Tzouvanas et al., 2019), Danso et. all. (2019) which states that high stakeholder integration will increase environmental performance that can improve financial performance (Danso et al., 2019), and Petitjean (2019) which states that concern for environmental performance during a crisis can increase financial performance (Petitjean, 2019). Based on these studies, environmental performance and environmental disclosure have inconsistent effects that can be negative, positive or have no effect at all, so it is interesting to be researched.

One of the important things that can influence company performance and become the basis of organizational members in carrying out each of their activities is organization culture (Jatiningrum, Musadieq, \& Prasetya, 2016). he organizational culture that influences company performance will affect the competitive advantage of the company which also affects financial performance (Martí-Ballester, 2017). Therefore, organization culture will affect a company's financial performance. Organizational culture not only affects company performance but also affects other activities such as some international companies where the organization culture can predict the sustainability of the company (Dyck et al, 2019), some Canadian childcare agencies where accountability and efficiency are increasing due to organizational culture, and leadership 
as the main thing in agencies (Vito, 2020), SMEs in the western region of Nigeria where organizational culture has a positive impact on total quality management (TQM) which improves the performance of SMEs (Eniola et al, 2019), restaurants in the USA where the organizational culture positively impacts the market orientation of the restaurants (Jogaratnam, 2017), and power companies in Spain where the organization culture positively impacts the safety of the electricity company (Silla et al, 2017). From the results of previous studies, organization culture has a positive impact on company activities.

This study will analyze financial performance influenced by environmental performance and environmental disclosure. The latest thing from this study is that organizational culture moderates the effects of environmental performance and disclosure. Organization Culture as a pattern of solving external and internal problems that are applied consistently to a group, as the correct way of looking at, thinking about, and solving the problems faced (Zhao, 2007). Culture or organizational culture can be said as the quality of life in an organization, manifested in the rules or norms, work procedures, work habits, leadership style (operating styles of principals) of a superior or subordinate (Tsai, 2011). Organizational culture as moderation can increase the effect of environmental performance and environmental disclosure on financial performance.

\section{LITERATURE REVIEW}

\section{Theory}

According to Haniffa and Cooke (2005), the legitimacy theory states that companies conduct their activities based on legal values because they have contracts with the community and companies try to connect various influential groups to get legitimacy from these groups (Fauzi et al, 2016; Mandaika \& Salim, 2015). The company must realize that the company's relationship with the environment and the community where the company is active will affect the company's survival. Therefore, the environment in which the company carries out activities must be considered. Another thing related to the theory of legitimacy is stakeholder theory. According to Sugiharto (2005) stakeholder theory states that a company must provide benefits for its stakeholders (shareholders, suppliers, creditors, consumers, government, and society) so it does not only operate for its own interests (Fauzi et al., 2016; Mandaika \& Salim, 2015). The basic principle of stakeholder theory is that company success is strongly influenced by stakeholders and this influences the company's long-term goals (Danso et al., 2019). Thus, the support given by stakeholders is very influential on the existence of a company. Therefore the company must seek support from stakeholders in order to survive.

In a competitive economy, globalization, and the development of information technology today, companies should do environmental performance. Environmental performance is carried out with the aim of protecting the environment and encouraging innovation towards a sustainable green culture for the health of the organization's economy (García-Machado \& Martínez-Ávila, 2019). Environmental performance may be achieved when companies redesign their productivity, use environmentally friendly technologies, and minimize and utilize unused resources (García-Machado \& Martínez-Ávila, 2019). The company's concern for the environment is an added value for the company and this will provide a positive signal for investors that will attract investors' interest and enthusiasm so as to be able to provide positive value which will further increase the company's profitability. The company must realize that its 
success in achieving its goals is not only influenced by internal factors but also by external factors that surround them.

Current environmental problems attract people's attention, influence consumer consumption, change willingness to buy environmentally friendly goods and increase demand for environmental disclosure (Wang et al., 2020). Environmental problems are now more serious, so companies have been asked to do environmental disclosure in almost all countries in the world. As with companies listed on the Shanghai and Shenzhen stock exchanges, all of which have to do environmental disclosure and CSR in their annual reports (Wang et al., 2020). For environmental disclosure to run well and satisfactorily, this activity needs to be monitored properly and adequately from both the government and public participation (Wang et al., 2020). Companies that realize that financial performance will be positively influenced by environmental disclosure will improve the quality of disclosure. In addition, the government is expected to be able to create relevant laws and regulations and stimulate companies to make environmental disclosures spontaneously (Wang et al., 2020).

Schein (2010) states that organizational culture is a dynamic process that is created due to interactions between individuals and the existence of a force that stabilizes it in the social order with rules as its control (Vito, 2020). Schein (2010) also explains that organizational culture is influenced by leaders through values, behavior, regulating rhythm by instilling organizational culture (Vito, 2020). Leaders' influence includes' key mechanisms' which consist of what must be considered, giving rewards and responses, reacting to crises, how to manage resource allocation and rewards, role modeling, coaching, teaching, promoting and disciplining employees. In addition, organization culture also limits leadership behaviors and practices. This includes 'secondary mechanisms' consisting of organizational structures, procedures, symbols, infrastructure, company experience, and statements related to organizational values (Vito, 2020). According to Schein (1996), organization culture consists of values and beliefs which then shape perception and behavior (Dyck et al., 2019). Organizational culture can be associated with something that can be predicted for the survival of the company such as financial welfare, social welfare, ecological well-being, or the balance of the three that belong to the organization that is prioritized for attention, discussion and business (Dyck et al., 2019). Harris (1998) put forward the characteristics of culture in organizations that are referred to as dimensions of the organization namely: (1) goals and mission, (2) attitudes, beliefs, principles, and philosophies, (3) priorities, values, ethics, status, and reward system, (4) norms and regulations, (5) organizational structure, and technology design, (6) policies, procedures and processes, (7) communication systems, language, and terminology, (8) supervision , reporting, and personal practice, (9) making decisions, solving problems and conflict resolution, (10) compensation, recognition, and promotion, (11) work space and environment, and (12) leadership.

\section{Hypothesis Development}

At present, the demand that cannot be avoided for companies in Indonesia is environmental performance. The company realizes that its success in achieving its goals is not only influenced by internal factors but also by external factors that surround them. This is an activity of companies that care about the environment and provide added value to a company, and it is a positive signal for investors in considering decision making so that it can provide positive values that will increase company profitability which is a measure of corporate financial 
performance (Danso et al., 2019). The results of research by Liu (2020) and Tzouvanas (2019) show that financial performance is positively influenced by environmental performance (Liu, 2020; Tzouvanas et al., 2019). In addition, the influence of leadership integration (Danso et al., 2019) will improve environmental performance which in turn will improve financial performance especially during crises (Petitjean, 2019). Based on the description, the first hypothesis to be tested is

$\mathrm{H}_{1}=$ Financial performance is positively influenced by environmental performance.

Environmental Disclosure has the power to reduce the occurrence of information asymmetry and is expected to improve the value and image of the company and as a communication tool in informing social and environmental impacts. Longoni and Cagliano (2018) and Ali Ahmadi, et al (2017) revealed that where financial performance is strongly influenced positively by high environmental disclosure (Ahmadi \& Bouri, 2017; Longoni \& Cagliano, 2018). Based on the description, the second hypothesis to be tested is

$\mathrm{H} 2=$ Financial performance is positively influenced by environmental disclosure

Organizations that grow and develop well are expected to pay attention to environmental performance and disclosure optimally. With this activity, the company's financial performance can improve. Therefore, companies must implement these activities into an organizational culture. Organizational Culture applied by companies can increase company activities such as increasing accountability and efficiency in several childcare agencies (Vito, 2020), having a positive impact on TQM in SMEs (Eniola et al., 2019), and having a positive impact on restaurants in the USA (Jogaratnam, 2017). Based on the description, the third and fourth hypotheses to be tested are

$\mathrm{H}_{3}=$ The effect of environmental performance on financial performance is strengthened by organizational culture as a moderating variable.

$\mathrm{H}_{4}=$ The effect of environmental disclosure on financial performance is strengthened by organization culture as a moderating variable to strengthen.

\section{METHODS}

This study uses a population and sample population of manufacturing companies listed on the IDX. The total population used is 163 companies that are members of PROPER with gold, green and blue ratings, have a positive ROA value, and are listed on the IDX during the 20142017 period. Samples that met these criteria from 2014-2017 were 145 samples with details included in the rankings as green as 19 samples and as many as 147 samples. All data in the form of secondary data taken from each company's annual report.

The dependent variable used is financial performance. The company's ability to manage and control existing resources is judged by the amount of financial performance. In this study, Return on Assets (ROA) is used to measure financial performance (Wang et al., 2020). ROA ratio is more appropriate to be used to compare companies engaged in the same field or to compare company performance from one period to the next. The independent variable consists 
of environmental performance and disclosure. Environmental Performance is measured based on the Minister of Environment Decree No. 06 of 2013 Proper color ranking with the criteria of Gold, Green, Blue, Red and Black (Indonesia, 2013). Proper criteria include (1) compliance criteria (2) criteria for evaluating aspects beyond the requirements (beyond compliance). The obedience criteria are used for ranking blue, red, and black. The criteria for evaluating aspects beyond the requirements (beyond compliance) are used for green and gold ranking. Criteria for compliance include (1) environmental documents or environmental permits (2) management of hazardous and toxic waste (3) control of air pollution and (4) control of water pollution. Criteria for evaluating aspects beyond the requirements (beyond compliance) include: (1) community empowerment (2) utilization of resources consisting of energy, hazardous waste, and 3R (reduce, reuse, recycle), reduction of air pollution, reduction of water pollution, and biodiversity protection (3) environmental management systems (4) preparation of environmental management performance documents (Indonesia, 2013). Disclosure of information relating to the environment and set forth in the company's annual report is environmental disclosure. This disclosure is measured using the Global Reporting Index (GRI) (Nurleli \& Faisal, 2017). According to Husin and Olesen (2012), indicators measuring environmental disclosure use content analysis which can be seen in table 1 (Nurleli \& Faisal, 2017). The moderting variable used is organization culture. Schein (2010) states that organizational culture is a dynamic process that is created due to interactions between individuals and the existence of a force that stabilizes it in the social order with rules as its control (Vito, 2020). The measurement of Organization Culture has been revealed by Harris (1998) where the cultural characteristics in an organization are referred to as the dimensions of the organization. These characteristics consist of (1) goals and mission, (2) attitudes, beliefs, principles, and philosophies, (3) priorities, values, ethics, status, and reward systems, (4) norms and regulations, (5) design of organizational structures, and technology, (6) policies, procedures, and processes, (7) communication systems, language and terminology, (8) supervision, reporting, and personal practice, (9) making decisions, solving problems, and conflict resolution, (10) compensation, recognition, and promotion, (11) work space and environment, and (12) leadership.

Measurement of financial performance that is influenced by environmental performance and disclosure moderated by organizational culture uses a linear regression equation. The linear regression equation model used is:

$$
F P=\beta_{0}+\beta_{1} E P+\beta_{2} E D+\beta_{3} O C+\beta_{4} E P * O C+\beta_{5} E D * O C+\varepsilon
$$

where FP (Financial Performance), EP (Environmental Performance), ED (Environmental Disclosure) and OC (Organization Culture). 
Print ISSN: 2053-4019(Print), Online ISSN: 2053-4027(Online)

Table 1. Rules that are applied in determining the form of environmental information disclosure

\begin{tabular}{|c|c|c|}
\hline $\begin{array}{l}\text { Form of } \\
\text { Disclosure }\end{array}$ & Applied Rules & Measurement \\
\hline Without form & Not applied & 0 \\
\hline Narration & $\begin{array}{l}\text { Although sentences are found, as a unit context and } \\
\text { capture the theme of disclosure of environmental } \\
\text { information while minimizing information loss, it is } \\
\text { considered a minimum context unit because it gives } \\
\text { little meaning when compared to other context units. } \\
\text { Therefore, the theme of disclosure of environmental } \\
\text { information which is located in only one sentence is } \\
\text { considered to have been a very limited discussion } \\
\text { and will be recorded as "clear" }\end{array}$ & 1 \\
\hline $\begin{array}{l}\text { Narrative with } \\
\text { Numbers }\end{array}$ & $\begin{array}{l}\text { Some themes are found in narrative and numeric } \\
\text { forms but with limited explanation (no more than } \\
\text { one sentence) will not be categorized as "very } \\
\text { descriptive". But it will be interpreted as a limited } \\
\text { discussion and recorded and counted as "clear". }\end{array}$ & 2 \\
\hline Visual image & $\begin{array}{l}\text { Visual image is a broader unit context, including the } \\
\text { text that surrounds it. Therefore, to distinguish } \\
\text { "clear" and "very descriptive", the theme of } \\
\text { disclosure of environmental information found in a } \\
\text { visual image in which there is already an illustration } \\
\text { directly interpreted does not provide enough } \\
\text { discussion about the visual image. This theme is } \\
\text { categorized as "clear". The theme of environmental } \\
\text { disclosure in the visual image was noted as "very } \\
\text { descriptive ", if the narration is provided using more } \\
\text { than one sentence delivered before and after the } \\
\text { visual image. }\end{array}$ & 3 \\
\hline
\end{tabular}

Source : Husin dan Olesen (2012) (Nurleli \& Faisal, 2017)

Linear regression equations are said to be good if they are normally distributed, do not contain multicollinearity, autocorrelation and heteroscedasticity. To test whether the research variables have a normal distribution or not do the normality test. Data that is normally distributed can be known through the distribution of points that follow the diagonal axis. To see whether there is a high correlation between independent variables in a multiple regression model, a multicollinearity test is performed. Multicollinearity test with SPSS is done with a regression test, with a benchmark value of VIF (variance inflation factor). To see whether there is an unequal variance from one residual to another, a heteroscedasticity test is performed. Heteroscedasticity testing is done by looking at the distribution of data in scatter plots. To find out whether or not there is a correlation that occurs between residuals in one observation with other observations in the regression model autocorrelation test is performed. This autocorrelation test compares the Durbin-Watson count (DW) with its critical values (dL and $\mathrm{dU})$. This test is also called the Durbin Watson statistical test. Multiple linear regression testing was conducted to determine the effect of the independent variable Environmental performance 
and Environmental disclosure on the dependent variable Financial Performance. This equation is formulated as follows:

$$
\mathrm{Y}=\mathrm{a}+\mathrm{b}_{1} \mathrm{X}_{1}+\mathrm{b}_{2} \mathrm{X}_{2}
$$

where $\mathrm{Y}$ is financial performance, $\mathrm{a}$ is konstanta, $\mathrm{b}_{1} \mathrm{~b}_{2}$ is regresi coefficient, $\mathrm{X}_{1}$ is environmental performance and $\mathrm{X}_{2}$ is environmental disclosure.

To find out how closely the relationship between the independent and dependent variables is performed a correlation test. In addition the calculation of the coefficient of determination is done to find out how much influence the independent variable has on the dependent. All of these tests use SPSS 20 software to process the data.

\section{RESULT}

\section{Descriptive Analysis Test}

Descriptive analysis test results for all the dependent, independent, and moderating variables used show that the financial performance variable obtained an average value in 2014 of 10.26 , 2015 of $9.35,2016$ of 9.87 and 2017 of 9,47 with a range of scores from 0.1 to 56.1. In the environmental performance variable, the average value in 2014 was 3,11, in 2015 it was 3,09, 2016 was 3,09, and in 2017 it was 3.11 with a range of 3 - 4 scores. In the Environmental Disclosure variable, the average value in 2014 was 0.07 , in 2015 it was $0.08,2016$ was 0.07 and in 2017 it was 0.07 with a range of 0-0.23. In the Organization Culture variable, the average value in 2014 was 0.8919 , in 2015 it was $0.8824,2016$ was 0.8851 and in 2017 it was 0.8844 with a score range of $0.4-1$

\section{Classic assumption test}

Normality test, heteroscedasticity test, multicollinearity test, and autocorrelation test are types of classical assumptions testing. The results of the normality test carried out using the Kolmogorov-Smirnov SPSS 20 software test get the results of the unstandadized residual values are as follows.

1. The value of $\mathrm{N}$ is 163

2. The Normal Parameters value consisting of the mean is $0 \mathrm{E}-7$ and the standard deviation is 1.53546359.

3. The Most Extreme Differences value consisting of absolute is 0.057 , positive is 0.057 , and negative is -0.046 .

4. The value of kolmogorov - sminov $\mathrm{Z}$ is 0.725 .

5. Asymp Value. Sig. (2-tailed) is 0.669 .

The results of the normality test with Kolmogorov-Smirnov get asymp values. Sig. (2tailed) of 0.669 .

Multicollinearity test results using SPSS 20 software shows the coefficient of multicollinearity is as follows.

1. The Environmental performance model gets a collinearity statistical value for tolerance of 0.881 and VIF of 1.135 .

2. The Environmental disclosure model gets a collinearity statistical value for tolerance of 0.881 and VIF of 1.135 . 
The results of the multicollinearity coefficient test on the independent variable resulted in tolerance values $>0.1$ and VIF values $<10$.

Heteroscedasticity test results on the research variables using scatter plots. The results show the points spread above and below the number 0 on the $\mathrm{Y}$ axis and the pattern shown is not clear.

The autocorrelation test results presented using SPSS 20 software show the autocorrelation test values using Durbin-Watson yielded a value of 1.809.

\section{Multiple Regression Test}

The results of the multiple regression analysis of the dependent and independent variables in this study indicate the resulting regression coefficient values are as follows.

1. In the Constant model, the value of unstandardized coefficients B is $-7,319$, std. Error 2,750, $\mathrm{t}$ of $-2,661$ and Sig. Is 0.009 .

2. In the Environmental Performance model, the unstandardized coefficient B value is 5.2, std. Error 1.605, Beta standardized coefficients of $0.247, \mathrm{t}$ of -3.24 and Sig. Is 0.001 .

3. In the Environmental Disclosure model, the value of unstandardized coefficients B is 3,463, std. Error 0.993, Beta standardized coefficients are 0.266, $\mathrm{t}$ is 3.488 and Sig. Is 0.001 .

Based on the test results obtained by the multiple regression model are:.

$$
\mathrm{FP}=-7,319+5,2 \mathrm{EP}+3,463 \mathrm{ED}
$$

The equation shows that the constant value is $-7,319$. The value of the regression coefficient for environmental performance variables is 5.2 and the value of environmental disclosure is 3.463 .

\section{Correlation and Determination Test}

The results of correlation and determination testing on the dependent and independent variables in this study can be seen The results of correlation and determination testing on the dependent and independent variables of the model used for this study show a summary of the coefficient of determination produced is the value of $R$ is 0.422 , the value of $R^{2}$ is 0.178 , adjusted $R^{2}$ is 0.167 and std. Error of the estimate is 1.54503 . These results indicate that the coefficient of determination (R square) produced is 0.178 or $17.8 \%$.

\section{Hypothesis Testing Results}

Hypothesis test results where financial performance is directly affected by environmental performance and disclosure are the same as the results of multiple linear regression tests which are partial tests ( $\mathrm{t}$ test) coefficients where the independent variable environmental performance has a tcount of 3.240 and a p value of 0.001 . The independent variable environmental disclosure has a $t_{\text {count }}$ of 3.488 and a $p$ value of 0.001 .

Hypothesis test results in which financial performance is influenced by environmental performance and disclosure moderated by organization culture are as follows.

1. In the Constant model, the value of unstandardized coefficients B is $-118,122$, std. Error $64,902, \mathrm{t}$ equal to -1.82 and Sig. Is 0.071 . 
2. In the Environmental Performance model, the value of unstandardized coefficients B is 69.3385, std. Error 38,242, Beta standardized coefficients are 3,302, t are 1,814 and Sig. Is 0.072 .

3. In the Environmental Disclosure model, the value of the unstandardized coefficients B is 9.994, std. Error 7,878, Beta standardized coefficients of -0.769 , t equal to -1.269 and Sig. Is 0.206 .

4. In the Organization Culture model, the value of unstandardized coefficients B is 113,487 , std. Error 65,148 , Beta standardized coefficients are 7,538, $\mathrm{t}$ is 1,742 and Sig. Is 0.083 .

5. In the Environmental Performance model that is moderated by Organization Culture, the value of unstandardized coefficients B is $-65,501$, std. Error 38,359, Beta standardized coefficients of $-8,575, t$ equal to $-1,708$ and Sig. Is 0.09 .

6. In the Environmental Disclosure model that is moderated by Organization Culture, the value of the unstandardized coefficients B is 13,313, std. Error 8,482, Beta standardized coefficients were $1,019, \mathrm{t}$ was 1.57 and Sig. Is 0.119.

The multiple linear regression equation of financial performance that is influenced by environmental performance and disclosure and is moderated by organization culture is as follows.

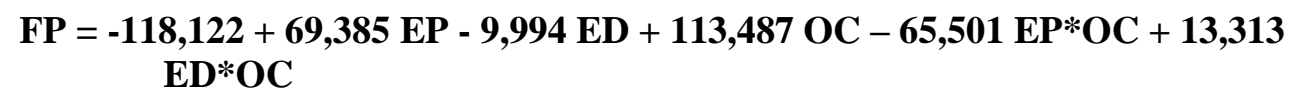

The equation shows that the environmental performance variable which is moderated by organization culture has a coefficient - 65,501 and the significance is 0.090 and environmental disclosure is moderated by organizational culture has a coefficient of 13,313 and a significance of 0.119 .

\section{DISCUSSION}

Based on the descriptive analysis test that the average value of the dependent variable of financial performance tends to fluctuate up and down in the 2014-2017 time span. For independent variables, environmental performance tends to decrease in the 2014-2016 timeframe, but again increased in 2017. For environmental disclosure, the variable increased in 2015 but declined in subsequent years. For the moderating organization culture variable, it tends to fluctuate up and down in the 2014-2017 time span. Financial performance conditions in the company during the 2014-2017 period which are members of PROPER and listed on the IDX experience financial instability every year. Companies that are very concerned about the environment show the value of environmental performance has increased and occurred in 2017. Disclosures related to environmental management are also not good because it has decreased after 2015. The implementation of organization culture activities in the company as a research sample is also not so good because the average value fluctuating up and down.

From the classical assumption test it appears that the data are normally distributed because the results of the normality test with kolmogorov-smirnov get asymp values. Sig. (2-tailed) of $0.669>0.05$. Furthermore, in this study multicollinity did not occur in the independent variables of environmental performance and disclosure because multicollinearity test results showed tolerance values $>0.1$ and VIF values $<10$. Then, there was no violation of heteroscedasticity in 
the multiple regression model of this study because heteroscedasticity test results showed a point of existing spread above and below the number 0 on the $\mathrm{Y}$ axis and the pattern that occurs is not clear. And finally, there is no autocorrelation between the dependent and independent variables in this study because the Durbin-Watson value of the autocorrelation test results is 1.809 outside the critical value ( $\mathrm{dL}$ and $\mathrm{dU}$ ) where the critical value $\mathrm{dL}=1.7191$ and $\mathrm{dU}=$ 1.7687 with a sample size $n=163, \leq 0.05$

The results of multiple regression tests on financial performance that are influenced by environmental performance and disclosure show that financial performance has a significant positive effect on environmental performance because the coefficient is positive and significant value $<0.05$ so that the first hypothesis related to financial performance is positively influenced by environmental performance received. The other thing from the results of this test is that financial performance has a significant positive effect on environmental disclosure because the coefficient value is positive and the value is significant $<0.05$ so that the second hypothesis related to financial performance that is positively influenced by environmental disclosure is accepted. These results are in line with research conducted by Danso (2019), Liu (2020), Tzouvanas (2019) and Petitjean (2019) where environmental performance is positively related to financial performance (Danso et al., 2019; Liu, 2020; Petitjean, 2019; Tzouvanas et al., 2019). Companies that care about the environment will get financial added value for a company, and it is a positive signal for investors in considering decision making so that it can provide positive values that will increase company profitability which is a measure of corporate financial performance (Danso et al., 2019). Likewise with environmental disclosure where the results of this study are in accordance with those conducted by Longoni and Cagliano (2018) and Ahmadi, et al (2017) where financial performance is positively influenced by high environmental disclosure (Ahmadi \& Bouri, 2017; Longoni \& Cagliano, 2018). Companies that carry out environmental disclosure will gain social legitimacy from stakeholders and maximize their financial strength in the long run, because corporate environmental disclosure is valuable information that the company is very concerned about the environment so investors make that information a consideration in making investment decisions that will have an impact on increasing profitability a company that will automatically improve the company's financial performance. However, the correlation and determination between environmental performance and disclosure to financial performance is quite low at $17.8 \%$ but it is significant because the significance value is <0.05. Companies that care about the environment can affect the company's finances even though the value of its influence is not large. Thus, companies that do not care about the environment will experience a decline in corporate finances and stakeholder trust because one of the things that must be done by the company at this time is to care about the environment.

The results of multiple linear tests on environmental performance variables that are moderated by organizational culture to financial performance show that the coefficient of environmental performance moderated by organizational culture has decreased by 70,701 and the significance value is $>0.05$. This shows that organizational culture weakens the value of environmental performance and does not significantly influence financial performance. Therefore, the third hypothesis regarding the effect of environmental performance on financial performance is strengthened by organizational culture as a moderating variable that is rejected. However, the coefficient on environmental performance moderated by organization culture has increased by 
9.85 and the significance value is $>0.05$. This shows that organization culture strengthens the value of environmental disclosure but does not significantly influence financial performance. Therefore, the fourth hypothesis related to the effect of environmental disclosure on financial performance is strengthened by organizational culture as a moderating variable rejected. These results are not the same as research conducted by Vito (2020) where organizational culture applied by companies can increase company activities such as increasing accountability and efficiency in some childcare agencies (Vito, 2020). The indicators contained in the organization culture in this study have not influenced the company's financial performance. Although there is a strengthening in environmental disclosure, it is not strong so it has no effect on financial performance. Based on these results, there must be indicators in the organizational culture that can influence environmental performance and disclosure strongly so that it can have a positive impact on financial performance such as the TQM in Nigerian SMEs (Eniola et al., 2019) and restaurants in the USA (Jogaratnam, 2017).

\section{CONCLUSION}

At this time, companies must be more concerned about the environment to be able to improve the performance of their companies. Environmental performance and disclosure is an activity carried out by a company in improving its performance. The results of this study indicate that financial performance is positively influenced by environmental performance and disclosure and is significant where the coefficient values are respectively 5.2 and 3.463 with significant values $<0.05$. Therefore, hypotheses related to financial performance that are positively influenced by environmental performance and disclosure are accepted. The moderating organization culture variable in this study cannot significantly influence environmental performance and disclosure. This organizational culture weakened environmental performance by 70,701 and strengthened environmental disclosure by 9.85 . However, due to its significant value $>0.05$, the moderating organization culture variable did not have a significant effect so the hypothesis related to the effect of environmental performance and disclosure on financial performance was strengthened by organization culture as a moderating variable rejected. Companies that carry out environmental performance and disclosure will likely increase their financial performance. In addition, organization culture cannot strengthen the value of financial performance in companies that care about the environment.

\section{Reference}

Ahmadi, A., \& Bouri, A. (2017). The relationship between financial attributes, environmental performance and environmental disclosure: Empirical investigation on French firms listed on CAC 40. Management of Environmental Quality: An International Journal, 28(4), 490-506. https://doi.org/10.1108/MEQ-07-2015-0132

Al-ahdal, W. M., Alsamhi, M. H., Tabash, M. I., \& Farhan, N. H. S. (2020). The impact of corporate governance on financial performance of Indian and GCC listed firms: An empirical investigation. Research in International Business and Finance, 51(August 2019), 101083. https://doi.org/10.1016/j.ribaf.2019.101083

Baah, C., Jin, Z., \& Tang, L. (2020). Organizational and regulatory stakeholder pressures friends or foes to green logistics practices and financial performance: Investigating corporate reputation as a missing link. Journal of Cleaner Production, 247, 119125. 
European Journal of Business and Innovation Research

Vol.8, No.3.pp. 1-16, May 2020

Published by ECRTD-UK

Print ISSN: 2053-4019(Print), Online ISSN: 2053-4027(Online)

https://doi.org/10.1016/j.jclepro.2019.119125

Cui, Y., Zhang, Y., Guo, J., Hu, H., \& Meng, H. (2019). Top management team knowledge heterogeneity, ownership structure and financial performance: Evidence from Chinese IT listed companies. Technological Forecasting and Social Change, 140(December 2018), 14-21. https://doi.org/10.1016/j.techfore.2018.12.008

Danso, A., Adomako, S., Lartey, T., Amankwah-Amoah, J., \& Owusu-Yirenkyi, D. (2019). Stakeholder integration, environmental sustainability orientation and financial performance. Journal of Business Research, (July 2018), 0-1. https://doi.org/10.1016/j.jbusres.2019.02.038

Deswanto, R. B., \& Siregar, S. V. (2018). The associations between environmental disclosures with financial performance, environmental performance, and firm value. Social Responsibility Journal, 14(1), 180-193. https://doi.org/10.1108/SRJ-01-2017-0005

Dyck, B., Walker, K., \& Caza, A. (2019). Antecedents of sustainable organizing: A look at the relationship between organizational culture and the triple bottom line. Journal of Cleaner Production, 231, 1235-1247. https://doi.org/10.1016/j.jclepro.2019.05.287

Edwards, D. N., \& Pinkerton, E. (2020). Priced out of ownership: Quota leasing impacts on the financial performance of owner-operators. Marine Policy, 111(October), 103718. https://doi.org/10.1016/j.marpol.2019.103718

Eniola, A. A., Olorunleke, G. K., Akintimehin, O. O., Ojeka, J. D., \& Oyetunji, B. (2019). The impact of organizational culture on total quality management in SMEs in Nigeria. Heliyon, 5(8), e02293. https://doi.org/10.1016/j.heliyon.2019.e02293

Etriya, E., Scholten, V. E., Wubben, E. F. M., \& Omta, S. W. F. (Onno. (2019). The impact of networks on the innovative and financial performance of more entrepreneurial versus less entrepreneurial farmers in West Java, Indonesia. NJAS - Wageningen Journal of Life Sciences, 89(September), 100308. https://doi.org/10.1016/j.njas.2019.100308

Fauzi, A. S., Suransi, N. K., \& Alamsyah. (2016). Pengaruh GCG Dan CSR Trhadap Nilai Perusahaan Dengan Profitabilitas Sebagai Variabel Pemoderasi. Jurnal Infestasi, 12(1), $1-19$.

Franco, S., Caroli, M. G., Cappa, F., \& Del Chiappa, G. (2019). Are you good enough? CSR, quality management and corporate financial performance in the hospitality industry. International Journal of Hospitality Management, (September), 102395. https://doi.org/10.1016/j.ijhm.2019.102395

Gan, H., Park, M. S., \& Suh, S. H. (2020). Non-financial performance measures, CEO compensation, and firms' future value. Journal of Business Research, 110(January), 213227. https://doi.org/10.1016/j.jbusres.2020.01.002

García-Machado, J. J., \& Martínez-Ávila, M. (2019). Environmental performance and green culture: The mediating effect of green innovation. An application to the automotive industry. Sustainability (Switzerland), 11(18). https://doi.org/10.3390/su11184874

Haniffa, R. \& Cooke, T.E. (2005) Impact of Culture and Governance Structure on Corporate Social Reporting, Journal of Accounting and Public Policy, Vol. 24 Issue 5, p.391-430.

Harris, L. C. (1998). 'Cultural domination: the key to a market oriented culture?'. European 
European Journal of Business and Innovation Research

Vol.8, No.3.pp. 1-16, May 2020

Published by ECRTD-UK

Print ISSN: 2053-4019(Print), Online ISSN: 2053-4027(Online)

Journal of Marketing, 32, 3/4, 354 \pm 73 .

Harris, L. C. and Ogbonna, E. (1998). 'A three perspective approach to understanding culture in retail organizations'. Personnel Review, 27, 1/2, 104 \pm 23.

Indonesia, M. L. H. R. Peraturan Menteri Lingkungan Hidup Republik Indonesia Nomor 6 Tahun 2013 Tentang Program Penilaian Peringkat Kinerja Perusahaan Dalam Pengelolaan Lingkungan Hidup. , § (2013).

Iqbal, S., Nawaz, A., \& Ehsan, S. (2019). Financial performance and corporate governance in microfinance: Evidence from Asia. Journal of Asian Economics, 60, 1-13. https://doi.org/10.1016/j.asieco.2018.10.002

Jan, A., Marimuthu, M., \& @ Mat Isa, M. P. bin M. (2019). The nexus of sustainability practices and financial performance: From the perspective of Islamic banking. Journal of Cleaner Production, 228, 703-717. https://doi.org/10.1016/j.jclepro.2019.04.208

Jatiningrum, C. D., Musadieq, M. Al, \& Prasetya, A. (2016). Pengaruh Budaya Organisasi, Motivasi dan Kemampuan Terhadap Kinerja (Studi Pada Karyawan dan Agen PT Asuransi Jiwasraya Branch Office Malang). Jurnal Administrasi Bisnis, 39(1), 117-124. https://doi.org/10.1007/BF02133069

Jogaratnam, G. (2017). How organizational culture influences market orientation and business performance in the restaurant industry. Journal of Hospitality and Tourism Management, 31, 211-219. https://doi.org/10.1016/j.jhtm.2017.03.002

Kim, J., Kim, J., Lee, S. K., \& Tang, L. (Rebecca). (2020). Effects of epidemic disease outbreaks on financial performance of restaurants: Event study method approach. Journal of Hospitality and Tourism Management, 43(August 2019), 32-41. https://doi.org/10.1016/j.jhtm.2020.01.015

Lin, W. L., Cheah, J. H., Azali, M., Ho, J. A., \& Yip, N. (2019). Does firm size matter? Evidence on the impact of the green innovation strategy on corporate financial performance in the automotive sector. Journal of Cleaner Production, 229, 974-988. https://doi.org/10.1016/j.jclepro.2019.04.214

Liu, Z. (2020). Unraveling the complex relationship between environmental and financial performance — A multilevel longitudinal analysis. International Journal of Production Economics, 219(October 2018), 328-340. https://doi.org/10.1016/j.ijpe.2019.07.005

Longoni, A., \& Cagliano, R. (2018). Inclusive environmental disclosure practices and firm performance: The role of green supply chain management. International Journal of Operations and Production Management, 38(9), 1815-1835. https://doi.org/10.1108/IJOPM-12-2016-0728

Lu, L. W., \& Taylor, M. E. (2018). A study of the relationships among environmental performance, environmental disclosure, and financial performance. Asian Review of Accounting, 26(1), 107-130. https://doi.org/10.1108/ARA-01-2016-0010

Ma, W., Jin, M., Liu, Y., \& Xu, X. (2019). Empirical analysis of fractional differential equations model for relationship between enterprise management and financial performance. Chaos, Solitons and Fractals, 125, 17-23. https://doi.org/10.1016/j.chaos.2019.05.009

Mandaika, Y., \& Salim, H. (2015). Pengaruh Ukuran Perusahaan, Kinerja Keuangan, Tipe 
Industri, Dan Financial Leverage Terhadap Pengungkapan Corporate Social Responsibility: Studi Empiris Pada Perusahaan Manufaktur Yang Terdaftar Di Bursa Efek Indonesia Tahun 2011-2013. Jurnal Akuntansi, 8(2), 181-201. https://doi.org/10.25170/jara.v8i2.18

Martí-Ballester, C. P. (2017). Sustainable energy systems and company performance: Does the implementation of sustainable energy systems improve companies' financial performance? Journal of Cleaner Production, 162, S35-S50. https://doi.org/10.1016/j.jclepro.2016.12.015

Moon, H., \& Min, D. (2020). A DEA approach for evaluating the relationship between energy efficiency and financial performance for energy-intensive firms in Korea. Journal of Cleaner Production, 255, 120283. https://doi.org/10.1016/j.jclepro.2020.120283

Myšková, R., \& Hájek, P. (2017). Comprehensive assessment of firm financial performance using financial ratios and linguistic analysis of annual reports. Journal of International Studies, 10(4), 96-108. https://doi.org/10.14254/2071-8330.2017/10-4/7

Nurleli, \& Faisal. (2017). Pengaruh Pengungkapan Informasi Lingkungan Terhadap Kinerja Keuangan. Kajian Akuntansi, 16(1), 31-54.

Nyilasy, G., Gangadharbatla, H., \& Paladino, A. (2014). Perceived Greenwashing: The Interactive Effects of Green Advertising and Corporate Environmental Performance on Consumer Reactions. Journal of Business Ethics, 125(4), 693-707. https://doi.org/10.1007/s10551-013-1944-3

Petitjean, M. (2019). Eco-friendly policies and financial performance: Was the financial crisis a game changer for large US companies? Energy Economics, 80, 502-511. https://doi.org/10.1016/j.eneco.2019.01.028

Rezende, L. de A., Bansi, A. C., Alves, M. F. R., \& Galina, S. V. R. (2019). Take your time: Examining when green innovation affects financial performance in multinationals. Journal of Cleaner Production, 233, 993-1003. https://doi.org/10.1016/j.jclepro.2019.06.135

Sardo, F., Serrasqueiro, Z., \& Alves, H. (2018). On the relationship between intellectual capital and financial performance: A panel data analysis on SME hotels. International Journal of Hospitality Management, 75(March), 67-74. https://doi.org/10.1016/j.ijhm.2018.03.001

Silla, I., Navajas, J., \& Koves, G. K. (2017). Organizational culture and a safety-conscious work environment: The mediating role of employee communication satisfaction. Journal of Safety Research, 61, 121-127. https://doi.org/10.1016/j.jsr.2017.02.005

Titisari, K. H., \& Alviana, K. (2012). Pengaruh Environmental Performance Terhadap Economic Performance. Jurnal Akuntansi Dan Keuangan Indonesia, 9(1), 56-67. https://doi.org/10.21002/jaki.2012.04

Tjahjono, M. E. S. (2013). Pengaruh Kinerja Lingkungan Terhadap Nilai Perusahaan dan Kinerja Keuangan. Jurnal Ekonomi Universitas Esa Unggul, 4(1).

Tsai, Y. (2011). Relationship between organizational culture, leadership behavior and job satisfaction. BMC Health Services Research, 11. https://doi.org/10.1186/1472-6963-1198 
Tzouvanas, P., Kizys, R., Chatziantoniou, I., \& Sagitova, R. (2019). Environmental and financial performance in the European manufacturing sector: An analysis of extreme tail $\begin{array}{llll}\text { dependency. British Accounting } & & \end{array}$ https://doi.org/10.1016/j.bar.2019.100863

Ukko, J., Nasiri, M., Saunila, M., \& Rantala, T. (2019). Sustainability strategy as a moderator in the relationship between digital business strategy and financial performance. Journal of Cleaner Production, 236, 117626. https://doi.org/10.1016/j.jclepro.2019.117626

Valls Martínez, M. del C., \& Cruz Rambaud, S. (2019). Women on corporate boards and firm's financial performance. Women's Studies International Forum, 76(July), 102251. https://doi.org/10.1016/j.wsif.2019.102251

Vito, R. (2020). Key variations in organizational culture and leadership influence: A comparison between three children's mental health and child welfare agencies. Children $\begin{array}{llll}\text { and } \quad \text { Youth } & \text { Services } & 104600 .\end{array}$ https://doi.org/10.1016/j.childyouth.2019.104600

Wang, S., Wang, H., Wang, J., \& Yang, F. (2020). Does environmental information disclosure contribute to improve firm financial performance? An examination of the underlying mechanism. Science of the Total Environment, 714(96), 136855. https://doi.org/10.1016/j.scitotenv.2020.136855

Wany, E., Murni, S. A., \& , K. (2017). Pengaruh Corporate Environmental Performance Dan Corporate Social Accounting Disclosure Terhadap Corporate Economic Performance. Media Riset Akuntansi, Auditing Dan Informasi, 14(1), 1. https://doi.org/10.25105/mraai.v14i1.1751

Yu, W., Jacobs, M. A., Chavez, R., \& Yang, J. (2019). Dynamism, disruption orientation, and resilience in the supply chain and the impacts on financial performance: A dynamic capabilities perspective. International Journal of Production Economics, 218(July), 352362. https://doi.org/10.1016/j.ijpe.2019.07.013

Zhao, Y. (2007). Organisational Culture - a Comparison of Naspers and Tencent. (March). 